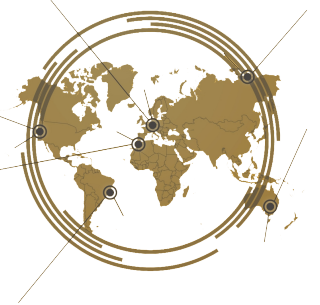

\title{
Collaborative writing and process writing approach: the effect and students perception
}

\author{
Winarti Winarti $^{1,2 *}$, Bambang Yudi Cahyono ${ }^{1}$ \\ ${ }^{1}$ Doctoral Program in English Language Teaching, Faculty of Letters, Universitas Negeri Malang, Indonesia, ${ }^{2}$ Universitas \\ Islam Negeri Maulana Malik Ibrahim Malang, Indonesia
}

Over the last few years, the researchers and practitioners have acknowledged the potential benefits attained from collaborative writing activity which was based on the wellknown theories of social constructivist and output hypothesis. Grounding from these theories, this study examined the collaborative writing combined with writing process approach to find out the effect of the task on students' ability in writing an explanation essay and students perception about the task. Two intact classes involving 30 students in each class participated in this study. One class as the experimental group completed the writing task using process writing in pairs while the other class completed the task individually. The students in experimental group were given a questionnaire right after the treatment to pool their views on the task. Post-test by administering the writing test was conducted to see the effect of the treatment. Data analysis revealed that students employing collaborative writing using process writing had better writing ability than students working individually. It was also found that most students felt that they gained many benefits from doing collaborative writing. These findings suggested that collaborative writing combined with process writing can be implemented in EFL writing pedagogy to improve students' writing ability.

Keywords: Collaborative writing, Process Writing Approach, Writing Ability

\section{INTRODUCTION}

OPEN ACCESS ISSN 25033492 (online)

*Correspondence: Winarti Winarti

winarti.wa@gmail.com

Received: 6th August 2020

Accepted: 21st September 2020

Published: 1st October 2020

Citation:

Winarti W and Cahyono BY (2020) Collaborative writing and process writing approach: the effect and students perception.

J. Eng. Educ. Society. 5:2. doi: 10.21070/jees.v5i2.773
Communicative language teaching has viewed that collaborative learning between or among students is a substantial activity to provide students with an opportunity to use the language they have learned in meaningful context. So, collaborative learning increases the opportunities students have to use the target language, solve the language problems together, thereby develop their skills in target language. Collaborative learning has theoretical and pedagogical supports which have claimed the importance of interaction to promote language learning. From theoretical perspective, the use of collaborative learning is supported by two major theories of language learning: the social constructivist view of learning which was built on the work of Vygotsky (1980), and the output hypothesis theory from Swain (1995). On the pedagogical side, several previous studies have emphasized the multiple benefits of collaborative learning in language learning Baleghizadeh (2009); Chen and Hird (2006); Dobao (2012); Fung (2010); Neumann and McDonough (2015); Storch (2005); Storch and Aldosari (2013); Wigglesworth and Storch (2009).

According to social constructivist theory proposed by well-known psychologist Vygotsky (1980), learning happens in a socially situated activity. It means that social interaction between 
students during language learning will influence students' cognitive development. In addition, novice students' cognitive development is developed in social interaction with more able students. The more able students (expert) provide the novice students with the appropriate help by stretching the novice students their current level toward their potential level of development Shehadeh (2011). The kind of assistance is commonly referred to scaffolding. The scaffolding can be in the form of giving valuable input, correcting mistakes, and giving feedback. Therefore, from the social constructivist perspective, students should be encouraged to participate in activities which foster interaction and co-construction of knowledge such as collaborative activity.

Furthermore, working together with other students to solve language problems in collaborative learning is also supported by the output hypothesis theory from Swain (1995). This theory has highlighted the importance of language production in which students need to be pushed to produce the language both spoken and written. According to Swain, it is not enough to expose students with valuable input to develop their language skill; however, they need to produce the language that they have already learned in real communication both spoken and written language. It is asserted that the production of the language triggers students to notice "the gap" in their knowledge, that is, the gaps between what they want to say and what they are able to say. These gaps will foster students to re-examine their linguistic knowledge they have and consider the input from their friends more closely which consequently leads to language learning. This process is assumed to be substantial element in second/foreign language development. Hence, by collaboration with others, students are able to get valuable language input and have opportunities to experiment through language production and to obtain feedback from their friends, so all those language activities will facilitate second/foreign language development.

On the pedagogical side, both literature and empirical studies have shown quite convincingly the learning gains obtained through collaborative learning. Collaborative learning, according to Johnson and Johnson (1987), has four defining characteristics: (a) positive interdependence, in which all group members participate to achieve the group goal; (b) individual accountability, in which each member of the group is held responsible for his or her own learning, which naturally contributes to group learning; (c) cooperation, in which students are expected to discuss, solve problems, and collaborate together; and (d) evaluation, in which members of the group review, evaluate, and reflect upon their work together to make the necessary changes. Harmer (2007) highlights the benefits of group interaction in promoting (1) language use opportunities, (2) positive interdependence and (3) individual accountability.

Collaborative learning can be applied to improve students' writing skill. Collaborative writing is a type of communicative tasks characterized by Swain and Lapkin (2001) as a task involving learners to comprehend, manipulate, produce, and interact in the target language they use. Not only that, it requires students to work together with their partner to produce language. According to Dobao (2012) collaborative writing is a task which involves two students or more who work together to produce a joint written text. Based on the previous definitions, the final requirement of the task is the joint written product in which students share the ownership of the text. However, producing shared text is one of activities in collaborative writing. Saunders (1989) proposed other activities in collaborative writing. These activities are different from one another on two factors, namely the tasks assigned and the interactive structures. The collaborative writing activities are co-writer, co-publisher, co-responders, co-editor, and writerhelper.

In light of the above theoretical arguments, a substantial amount of research has been empirically examined the effect of collaborative writing on L2 performance and learning. A study comparing the pair and individual work performing the edited task was conducted by Storch (2007). The study involved four intact classes which were assigned to correct the text to make the text have better accuracy. Students in one class was assigned to work in pair, whereas another class required the students to perform the task individually. The other two classes had opportunity to complete the task either in pair or individually. The analysis of edited text produced by the student working both in pairs and individually showed that the text edited by pair was not significantly different from the one edited by student working individually. However, the analysis of students talk during the interaction reported different result in which the pairs were able to resolve language problem interactively. It means that students had the opportunity to engage in using and reflecting the language which facilitated the language learning.

Another exploration of the role of collaborative writing on language learning was investigated by Wigglesworth and Storch (2009) and Storch (2005). The study compared the performance in writing argumentative text which completed by students working in pairs and individually. The students working in pairs had responsibility to complete the task together and produced one joint written text. The text produced by pairs and individuals were compared to see the effect of the collaborative writing on the fluency, complexity, and accuracy. The results of the study showed that students working in pairs did not produce a longer text compared to working individually. In term of complexity, there was no significantly different between the texts produced by students working in pairs and individual meaning that working collaboratively was not likely to give impact on grammatical complexity. However, the positive result on the accuracy of the text could be found when students working in pairs in which the students were able to produce the more accurate text.

A different study to examine the effect of collaborative writing was carried out by Shehadeh (2011). This study lasted for 16 weeks by assigning student to work collaboratively particularly in pairs and individually in writing several paragraphs. The post test was administered to compare the quality of the text produced which was determined by five elements of good 
writing namely content, organization, grammar, vocabulary, mechanics. The analysis of written text revealed that collaborative writing influence significantly the overall students writing ability. However, the areas of grammar and mechanics were not affected by collaborative writing as the texts produced by pairs was not significantly different from the texts produced individually.

The majority of previous studies investigating the role of collaborative learning on students writing ability focused on examining the text produced by students during completing the task as the measure of the effectiveness of collaborative writing, study by Shehadeh (2011) being an exception. In fact, the writing instruction is aimed to prepare students to produce the English text done individually. Therefore, further investigation involving pre-test and post-test was needed to be conducted to see the effect of collaborative writing after the treatment.

In process approach, writing is seen as recursive activity and do not occur in linear sequence and it requires cognitive process emphasizing on the importance of a recursive procedure of pre-writing, drafting, evaluating, and revising Hyland (2019). The writing activity starts with pre-writing in which students generate idea related to the topic and organize those ideas into correct structure as the text requires. The following activities were proceeded by asking students to have multiple drafts of written work as students revise and edit the draft to produce the final product. Discussion and feedback from teachers or other students will help students to revise the drafts. Since students get valuable input from others during completing multiple process, process approach is characterized as learner-centered approach Rusinovci (2015). As the consequences, the long processes done by students will develop students' metacognitive awareness, that is the ability to employ a certain strategy to write a piece of written text Hyland (2019).

Concerning process approach implemented in collaborative writing, several previous studies have attempted to investigate the effect on the improvement of students writing ability. A study involving 74 first year-preschool teaching students revealed that the writing success was affected by assigning the participant of the study to write the essay through the steps in the writing process Bayat (2014). Another study investigating the effect of scaffolding on EFL students' writing ability through the writing process found that the students writing ability has improved significantly and positively due to giving the scaffolding through process writing treatment and students felt that they could express the idea confidently on their writings Faraj (2015). This positive effect of process writing on students writing performance was also confirmed by other studies (Kolade (2012); Alodwan and Ibnian (2014); Alodwan and Ibnian (2014); Pour-Mohammadi et al. (2012).

Although a substantial amount of research has provided insight regarding how the process writing approach affect student writing performance, a little attention has been given to process writing performed collaboratively. The previous research only focused on assigning students to write through the steps of writing process done individually. However, the question arose whether the combined two writing activities led significantly to the improvement of students writing ability. Therefore, the purpose of the current study was to compare the impact of the collaborative and individual task using process writing approach. In addition, it also tried to investigate students' perception regarding their preference on collaborative learning using process writing.

\section{METHODS}

The present study was conducted to examine how students engaged in collaborative writing task particularly done in pairs through process writing affect Indonesia EFL students' ability in writing the explanation essay. Referring to the objectives of the present study, experimental research was employed since it enabled the researcher to estimate the effect of experimental treatment. To be more specific, this study used a quasiexperimental since it was impossible to randomly assign subjects to either experimental and control group due to the university system. In such a case, it was necessary to use subjects of study who were already organized into classes (intact class). 60 students in the fourth semester from Mathematic Department in one of public universities in Malang, East Java Indonesia participated in this study. The students were divided into 2 classes consisting of 30 students in each class. Students from class A were assigned to do collaborative writing in pairs, and those from class B were given a writing task done individually.

To see the effect of collaborative writing 10 meetings, including pre-test and post-test, were carried out by both experimental and control group. Prior to the treatment, the students in two classes were given a pre-test to make sure that there was no significant difference between the experimental and control groups with regard to students' writing ability. The students in each class had to write an explanation essay individually in the classroom as it was instructed in a writing prompt. The writing prompt demanded students to compose the explanation essay relevant to their context of the field in approximately 300-400 words. The students were given 90 minutes to finish their essay. The second meeting to the fourth meeting was administered to write the first explanation essay through process writing starting from pre-writing, drafting, giving feedback, revising/editing, and publishing. All students also obtained feedback from the lectured performed outside of the classroom. In the experimental group, all the activities done in pairs whereas in control group student wrote the essay individually. Writing the second explanation essay was executed from fifth meeting to ninth meeting. The activities were a repeat of the previous activities with different topic.

The last meeting that was tenth meeting was used to conduct post-test to measure the effect of collaborative writing combined with process writing on students' writing ability. The students from both in experimental and control groups were given a writing prompt containing some instructions that the 
students had to follow. It is worth noting that slightly different prompts were chosen for the pre-test and post-test. The similarity was lied on the type of text that they had to write, the length of words, and time allotment that was provided to complete the test. Meanwhile, the post-test prompt used different topic from the pre-test prompt to avoid them from learning previous topic in pretest. In addition, the new topic in post-test was believed to make the test more challenging, and they would not consider it as routine assignment, so the different result on posttest could be attributed to the effect of collaborative writing.

Furthermore, after the treatment 30 students in the experimental group were given a set of questions to reveal their views on the activity and experience of completing the task. All the questions given to the students were the combination of closedended and open-ended questions in which they were provided with the choices of answer, and they needed to elaborate their answer for open-ended questions. They were encouraged to express their views freely by jotting down their answers on a piece of paper. There were 6 questions ranging from asking their preference to work collaboratively and their reason, their views on the activity, the problems they encountered during the process of collaborative writing, and what aspect of writing they discussed most and their reason. The data from the survey were analyzed manually by reading the sheet one by one and writing the answers on the table based on the order of questions and common answers.

The students' essays were rated by two raters using analytical scoring rubric. The scoring rubric consisted of five components, namely: content, organization, grammar, vocabulary, and mechanics. The content and organization got the highest weight (6) because the knowledge of the topic and the development of the ideas were essential in explanation essay for the sake of academic purposes. grammar and vocabulary were weight 5 , and mechanics was weight 3 . The reliability of the two raters was .885 , and it was considered good reliability according to Koo and $\mathrm{Li}$ (2016). The final score used as the score of students' writing was the average of the two raters' scores.

\section{RESULTS AND DISCUSSION}

\section{Result}

This section is intended to present the results of the study according to the order of research questions. It begins with the result of pre-test to examine the homogeneity of experimental and control group. Then, it proceeds to the presentation of the results of post-test to answer the research problem dealing with the effect of collaborative writing combined with process writing on students' writing ability. The last part is presenting the result of questionnaire to reveal students' perception on the task.

From the results of homogeneity test for pre-test score, it was found that the means from the two groups were homogeneous (seeTable 1). It can be seen from the test of homogeneity of variance showing that the $p$ value was .102 which was higher than the level of significance .05. As the means from two groups showed the level of homogeneity, further analysis employing ttest was conducted to compare the means. The result showed that the means from the two groups were not statistically different given that the $\mathrm{p}$ value was higher than the level of significance $(.177>.005)$. Based on the result of pre-test, it can be concluded that the two groups had homogeneous writing ability so that the treatment assigning the students to write collaboratively combined with process writing could be undertaken.

Referring to the first question, Table 2 summarizes the results of statistical analysis showing that the mean of overall writing ability for experimental group was higher than mean for control group. The mean for experimental group was 77.467 whereas the control group obtained mean of 60.787 . It also revealed that the means of students score working collaboratively for each element of writing quality were higher than that of working individually. The means from experimental group for five elements of writing quality were 21.1, 19.6, 13.6, 14.8 , and 8.35 for content, organization, grammar, vocabulary, and mechanics respectively. Based on the descriptive analysis, the experimental group appeared to have better writing ability compared to the control group for either overall writing ability and each element of writing. However, it was needed a further analysis whether the effect was significantly different or not.

From the results of the comparison of means between experimental and control groups, it was found that means for overall writing ability and for each element of writing were significantly different as the $p$ values were smaller than the level of significance .05 . It could be concluded that students engaging in collaborative writing had better writing ability than students working individually.

As stated earlier that 30 students in experimental groups were requested to answer some questions regarding their perception about the task. Students responses on the question asking their preference for collaborative writing showed that 10 students chose to do the task individually due to time efficiency and conflict between the students. One student wrote "When working alone I don't need to wait for my friend idea in developing my draft and I don't need to consider my friend idea because sometime it is difficult to accept the idea from our partner". They also stated that working together created conflict since there would be many various ideas and to get one idea for the draft was not easy job to be done. Some students felt that working together was time-consuming because they needed to discuss and had long argument to determine the best idea used in the draft. Some students stated "we have freedom to express our ideas on the draft if we write individually, and we can write right away the idea which come into our mind without waiting for our friends agreement."

Students who favored for collaborative writing asserted that the activity provided them with considerable benefits for learning English language. The activity enabled them to exchange the ideas as every member generated the idea of the assigned topic. One student wrote: "when working alone, we cannot exchange the idea so that our draft cannot be developed prop- 
TABLE 1 | The results of analysis for pretest score

Independent Samples Test

Levene's Test for Equality t-test for Equality of Means of Variances

\begin{tabular}{|c|c|c|c|c|c|c|c|}
\hline \multirow{3}{*}{ Score } & & $\mathrm{F}$ & Sig. & $\mathrm{t}$ & $\mathrm{df}$ & $\begin{array}{l}\text { Sig. } \\
\text { (2-tailed) }\end{array}$ & $\begin{array}{l}\text { Mean } \\
\text { Difference }\end{array}$ \\
\hline & $\begin{array}{l}\text { Equal variances } \\
\text { assumed }\end{array}$ & 2.758 & .102 & -1.366 & 58 & .177 & -5.4167 \\
\hline & $\begin{array}{l}\text { Equal variances } \\
\text { not assumed }\end{array}$ & & & -1.366 & 54.873 & .178 & -5.4167 \\
\hline
\end{tabular}

TABLE 2 | The results of analysis for post-test

\begin{tabular}{lllllll}
\hline & Max & \multicolumn{2}{l}{ Experimental } & Control & Sig. (2- \\
& score & Mean & SD & Mean & SD & tailed) \\
Total score & 100 & 77.467 & 10.3424 & 60.787 & 12.6136 & .000 \\
Content & 24 & 21.100 & 2.8929 & 17.100 & 3.8716 & .000 \\
$\begin{array}{l}\text { Organiza- } \\
\text { tion }\end{array}$ & 24 & 19.600 & 3.0240 & 14.300 & 3.2179 & .000 \\
Grammar & 20 & 13.583 & 2.8378 & 9.917 & 3.4418 & .000 \\
Vocabulary & 20 & 14.833 & 1.8492 & 12.667 & 2.7016 & .001 \\
Mechanics & 9 & 8.350 & 1.4571 & 6.800 & 1.6588 & .000 \\
\hline
\end{tabular}

erly. We can have a lot of ideas coming to our mind because we discuss and find the best idea for our draft". The activity also offered the students with the experience of how to express the idea and accept the idea as it forced them to discuss everything that needed in completing the draft starting from generating the ideas, drafting, revising and editing. Finally, by working together they could help each other. One student stated that they learned a lot from their partner especially vocabulary and grammar because they could ask questions dealing with vocabulary or grammar problem, and they could solve the problem together. By working together, they could share the knowledge, discus the material, give feedback, solve the problem together. One student wrote the following paragraph.

\begin{abstract}
"There will be several debates about how to put the ideas into the draft as every member had his/her own strong idea but working together makes us close each other and when we are making mistake or confused about the subject matter, we can ask our partner. When we do the activity alone, we don't have much opportunity to ask questions to our friend because they are busy doing their own task".
\end{abstract}

\section{Discussion}

With the respect to the last question asking which element of writing they discussed most during collaborative writing. Most of the students revealed that content was the most discussed element followed by vocabulary, grammar, organization and mechanics respectively. They argued that content was the most important element in writing a draft. One student wrote "Content is the most important one because the idea should be in line with the topic. If the idea is wrong our draft is useless although it has good vocabulary and grammar". Another student stated "it is content because it is the most difficult one to master the knowledge of topic and developed it using supporting ideas. When content is already fix, other elements seem to be easy". The other added "Because we need to generate interesting ideas to be put on our draft so that it can be developed into good essay".

The results of statistical analysis from the texts written by the students in the post test after the treatments revealed that the collaborative writing task assigning them to write an explanation essay had a positive effect on students' writing ability. It can be elaborated that the students who were exposed to a writing activity which involved more than one student working together to compose a jointly written essay proved to have a better ability in writing the essay than those who were assigned the writing activity done individually. Thus, the result of the study supported the preceding theories and studies which asserted that working together in composing a draft was believed to be beneficial for students in the process of learning the second or foreign language Dobao (2012); Mirzaei and Eslami (2015); Nassaji and Tian (2010); Shehadeh (2011); Storch (2005).

Collaborative writing not only had the positive effect on the overall writing ability, but also on each element of writing skill. With respect to content of the essay, the mean score from work- 
ing in pairs was significantly different from the mean of working individually meaning that working in pairs affected the content of essay better than working individually. The students in pairs were able to state general statement which explained the process relating to the scientific phenomenon. They also had a better ability to develop the general statement into relevant explanations using connective words. This ability was gained by having greater opportunity pairs had to engage in the task or interact with the other member since working in pairs forced each member to contribute to complete the task. This finding supports the finding of the previous study conducted by Shehadeh (2011) and Neumann and McDonough (2015) which claimed that collaborative writing offered opportunity for the students to discuss and elicit students' talk about the content which influenced the ability of students writing.

Regarding to the organization of essay, the students were required to organize the ideas into a good order of explanation essay. The students in pairs had better ability in this area in which the essays were skillfully organized to contain an introductory paragraph that identified the scientific phenomenon; body paragraph consisted of sequenced statements to explain how the scientific phenomenon happened and each sequenced statement was clearly elaborated with detailed and accurate illustrations; the concluding paragraph tied up the explanations in an interesting and creative way.

In term of grammar, working in pairs enabled the students to have better ability to use English structure effectively. Their drafts showed that simple present tense was used accurately to express the facts or theories which are categorized into general truths. Also, they concerned greatly with the use of subjectverb agreement as the result of simple present tense usage. It is worth noticing that the students' awareness regarding the aspect of grammar was gained through working in pairs. The students working in pairs were forced to fully participate and help each other in solving language related problems. They learned together how to arrange the words to express the ideas into good sentences using correct structure. This activity could help the students reaching higher level of understanding the form, function, and meaning of grammar rules that might not be obtained if they worked individually. The result on this area in this study is in line with the result of study investigated by Wigglesworth and Storch (2009) which reported that the accuracy of written text produced by students was affected by working collaboratively.

Referring to the aspect of vocabulary, working in pairs seemed to affect the effective use of technical words on the students' essay. The students were able to develop their ideas using effective and accurate words and most of their essays showed few misuses of vocabulary. The following is the example of vocabulary usage from the student' draft in pair work.

"First, you have to remember the formula of volume of cone. The formula is $1 / 3$ multiplied by the area of the base of cone multiplied by the height of cone. The shape of base of cone is circle and you have to use the area of circle to help you calculate the volume cone. The formula of area of circle is pr2. $\mathrm{p}$ is phi that has value of $22 / 7$ or 3,14 . $\mathrm{r} 2$ is the square radius of circle."

Based on the result of questionnaire given after the treatment, it was found that the most of the students felt that collaborative writing offered positive outcomes compared to working individually. They stated that working collaboratively during the completion of writing draft enabled them to share the ideas of the topic assigned. Sometimes, while working alone hindered them from expressing the ideas and made them think aloud to find the appropriate ideas. In addition, the activity facilitated them to develop the ideas well because there were available knowledge resources found in pairs that could be used to elaborate the ideas so that the draft they developed consisted of more detail information.

The second benefit of collaborative writing unveiled by the students is that they could divide the job of writing essay between the member or on the other words they could share the strength and weakness with others. For example, the strong one who had better knowledge of English could help the weak one to improve their skill while the weak one got valuable knowledge input. The last benefit the students got from the task is that they had a chance to give feedback each other to make a better quality of draft since they produced the jointly written draft so every member of the pair had the same responsibility for completing the assigned task. The same result was also found in the previous study investigating students' perception on collaborative writing Shehadeh (2011); Storch (2005) which revealed that the majority of students engaging in collaborative writing enjoyed the experience offered by a collaborative task and received many valuable benefit from it. As the conclusion, collaborative writing not only encouraged the students to share the knowledge they had to other members but also it gave them remarkable input they needed in improving the writing skill.

Aside from the benefits obtained by working together, collaborative writing also created some potential problems which could be detrimental to the positive features of collaborative writing. According to students' response, one of the problems arising during the completion of the task was a conflict between students as they had different ideas and often negotiated the best idea which should be put in the draft. Conflicts between or among the members are natural phenomena in collaborative learning and could be either positive or negative effect to the effectiveness of collaborative learning Fung (2010).

Conflict could be categorized into three types, namely cognitive, motivational, and socio-emotional conflict Näykki et al. (2014). The most conflict faced by pairs dealt with the cognitive problem given that they found difficulty in understanding the other members' thinking or negotiating multiple perspectives. Some students stated that their partner defended the ideas and enforced the other to accept the idea to be used in the draft. Other revealed that the conflict made them stand in solidarity 
between the member as they solved the problem together. The other problem that should be handled properly was humors. Humor could be a challenge for the collaborative learning as they often regarded as off task which influence the efficiency of completion the task. However, Humor actually could maintain the relationship of the member Fung (2010) and to handle negative emotion such as anxiety, frustration, boredom Lamminpää and Vesterinen (2018).

\section{CONCLUSION}

This present study attempted to investigate the effect of collaborative writing by comparing the writing ability completed after working in pairs and individuals through some steps in process writing starting from prewriting, drafting, revising/editing, and publishing. The results could add to the further supportive evidence that yielded the fundamental role of collaborative writing combined with process genre approach. More precisely, this study found that the combination of collaborative learning and process writing approach allowed students to share and discuss the knowledge needed in completing the task together.

\section{REFERENCES}

Alodwan, T. and Ibnian, S. S. (2014). The effect of using the process approach to writing on developing university students' essay writing skills in EFL. International Journal of Linguistic and Communication 2, 147-163.

Baleghizadeh, S. (2009). The effect of pair work on a word-building task. ELT Journal 64, 405-413. doi: 10.1093/elt/ccp097.

Bayat, N. (2014). Sürece dayalı yazma yaklaşımının yazma başarısı ve kaygısı üstündeki etkisi. Kuram ve Uygulamada Egitim Bilimleri 14, 1123-1141.

Chen, R. and Hird, B. (2006). Group Work in the Efl Classroom in China: A Closer Look. RELC Journal 37, 91-103. doi: 10.1177/0033688206063476.

Dobao, A. F. (2012). Collaborative writing tasks in the L2 classroom: Comparing group, pair, and individual work. Journal of Second Language Writing 21, 40-58. doi: 10.1016/j.jslw.2011.12.002.

Faraj, A. K. A. (2015). Scaffolding EFL Students 'Writing through the Writing Process Approach. Journal of Education and Practice 6, 131-142.

Fung, Y. M. (2010). Collaborative writing features. RELC Journal 41.

Harmer, J. (2007). The practice of English language teaching (Longman).

Hyland, K. (2019). Second language writing (Cambridge University Press).

Johnson, D. W. and Johnson, R. T. (1987). Learning together and alone: Cooperative, competitive, and individualistic learning (Prentice Hall).

Kolade, A. T. (2012). The Influence of Process Approach on English as Second Language Students' Performances in Essay Writing. English Language Teaching 5, 16-29. doi: 10.5539/elt.v5n3p16.

Koo, T. K. and Li, M. Y. (2016). A Guideline of Selecting and Reporting Intraclass Correlation Coefficients for Reliability Research. Journal of Chiropractic Medicine 15, 155-163. doi: 10.1016/j.jcm.2016.02.012.

Lamminpää, J. and Vesterinen, V.-M. (2018). The use of humour during a collaborative inquiry. International Journal of Science Education 40, 1718-1735. doi: 10.1080/09500693.2018.1508926.

Mirzaei, A. and Eslami, Z. R. (2015). ZPD-activated languaging and collaborative L2 writing. Educational Psychology 35, 5-25.

Nassaji, H. and Tian, J. (2010). Collaborative and individual output tasks and their effects on learning English phrasal verbs. Language Teaching Research 14, 397419. doi: 10.1177/1362168810375364.

Näykki, P., Järvelä, S., Kirschner, P. A., and Järvenoja, H. (2014). Socio-emotional conflict in collaborative learning-A process-oriented case study in a higher education context. International Journal of Educational Research 68, 1-14. doi: 10.1016/j.ijer.2014.07.001.

Neumann, H. and McDonough, K. (2015). Exploring student interaction during collaborative prewriting discussions and its relationship to L2 writing. Journal
Further, the activity eventually improved the students' writing ability which could be seen from the result of means for the posttest in which students working in collaborative writing had better mean significantly than those working individually. Thus, it is suggested that the task could be applied in teaching writing as pedagogical tool to improve students' writing ability and create conducive social atmosphere of learning English. In addition, some challenges might be found during the implementation of the task, and they could influence the effectiveness of the collaborative and teachers needed to handle those challenges by explaining the benefit provided by collaborative and rules that should be obeyed during collaborative writing.

\section{ACKNOWLEDGMENTS}

My sincere gratitude is forwarded to the anonymous reviewers and the editor who have given suggestions and corrections to the improvement of article. My appreciation is also addressed to Mathematics students Batch 2017 as the subjects of the study who have been cooperative and helpful during the collection of the data.

of Second Language Writing 27, 84-104. doi: 10.1016/j.jslw.2014.09.009.

Pour-Mohammadi, M., Abidin, M. J. Z., and Fong, C. L. (2012). The Effect of Process Writing Practice on the Writing Quality of Form One Students: A Case Study. Asian Social Science 8, 88-99. doi: 10.5539/ass.v8n3p88.

Rusinovci, X. (2015). Teaching Writing Through Process-Genre Based Approach. US-China Education Review A 5, 699-705. doi: 10.17265/2161-623x/2015.10a. 006.

Saunders, W. M. (1989). Collaborative writing tasks and peer interaction. International Journal of Educational Research 13, 101-112.

Shehadeh, A. (2011). Effects and student perceptions of collaborative writing in L2. Journal of Second Language Writing 20, 286-305. doi: 10.1016/j.jslw.2011. 05.010 .

Storch, N. (2005). Collaborative writing: Product, process, and students' reflections. Journal of Second Language Writing 14, 153-173.

Storch, N. (2007). Investigating the merits of pair work on a text editing task in ESL classes. Language Teaching Research 11, 143-159.

Storch, N. and Aldosari, A. (2013). Pairing learners in pair work activity. Language Teaching Research 17, 31-48. doi: 10.1177/1362168812457530.

Swain, M. (1995). Three Functions of Output in Second Language Learning. Principle and Practice in Applied Linguistics: Studies in Honor of H.G. Widdowson, 125-144.

Swain, M. and Lapkin, S. (2001). Focus on form through collaborative dialogue: Exploring task effects. Researching pedagogic tasks: Second language learning, teaching and testing, 99-118.

Vygotsky, L. S. (1980). The development of higher psychological processes (Harvard university press).

Wigglesworth, G. and Storch, N. (2009). Pair versus individual writing: Effects on fluency, complexity and accuracy. Language Testing 26, 445-466. doi: $10.1177 / 0265532209104670$.

Conflict of Interest Statement: The authors declare that the research was conducted in the absence of any commercial or financial relationships that could be construed as a potential conflict of interest.

Copyright (C) 2020 Winarti and Cahyono. This is an open-access article distributed under the terms of the Creative Commons Attribution License (CC BY). The use, distribution or reproduction in other forums is permitted, provided the original author(s) and the copyright owner(s) are credited and that the original publication in this journal is cited, in accordance with accepted academic practice. No use, distribution or reproduction is permitted which does not comply with these terms. 